
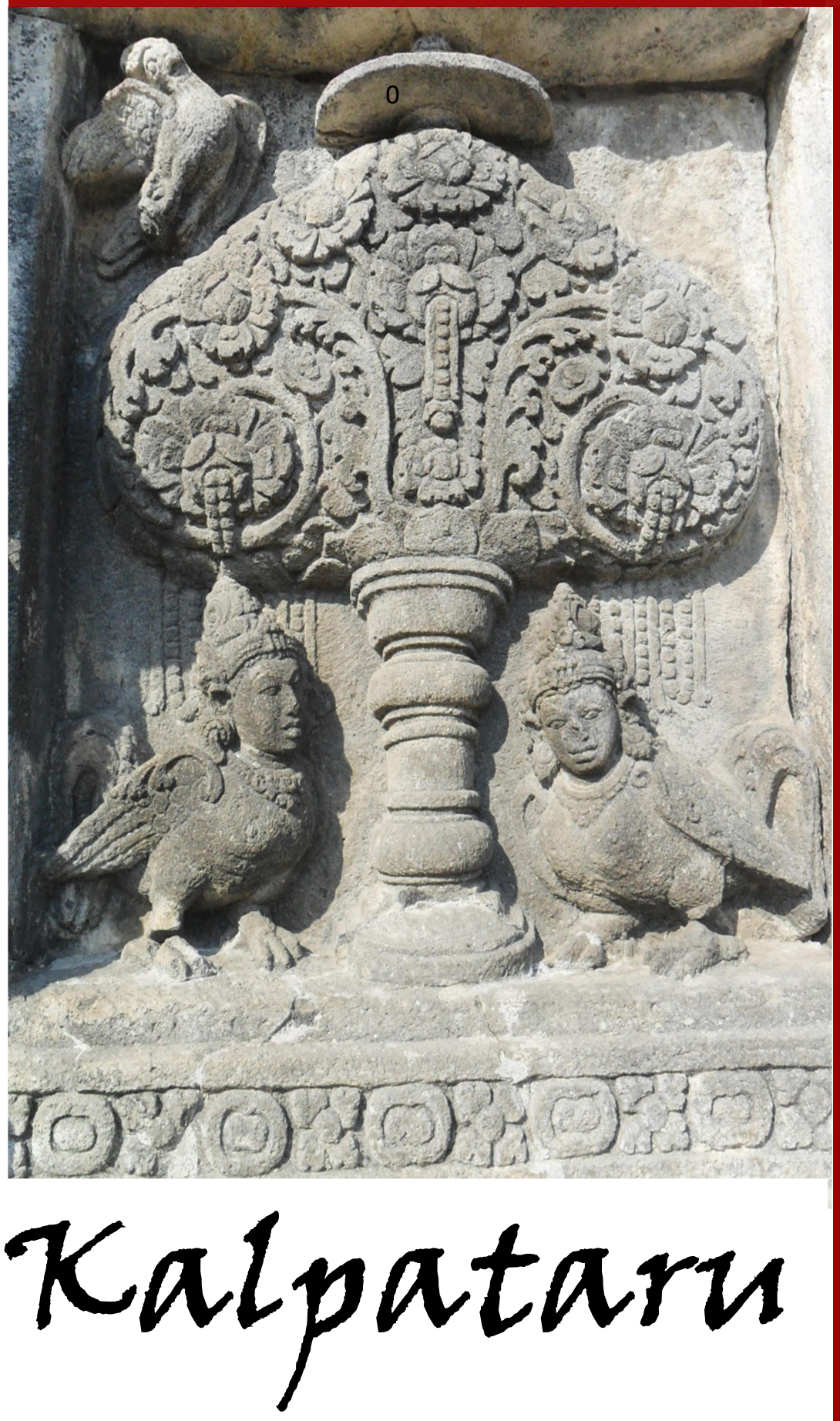

\author{
JURNAL SEJARAH DAN \\ PEMBELAJARAN SEJARAH
}

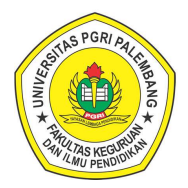

Program Studi Pendidikan Sejarah Jurusan Pendidikan IPS

Fakultas Keguruan dan IImu Pendidikan Universitas Persatuan Guru Republik Indonesia Palembang
Pengaruh Model Pembelajaran Student Facilitator and Explaining Terhadap Hasil Belajar Siswa Pada Mata Pelajaran Sejarah Kelas $X$ di SMA Negeri 3 Palembang

Sarinah, Nur Ahyani, Ahmad Zamhari

Pengaruh Model Pembelajaran Berbasis Masalah (PBM) Terhadap Hasil Belajar Siswa Pada Mata Pelajaran IPS Terpadu (Sejarah) Kelas VIII di SMP Negeri 2 Palembang

Neka Dapistri, Nur Ahyani, Ahmad Zamhari

Penerapan Media Pembelajaran Menggunakan Google Earth Dalam Materi Kondisi Masyarakat Indonesia Pada Masa Penjajahan Terhadap Hasil Belajar Siswa Pada Mata Pelajaran IPS Terpadu di SMP Quraniah Palembang

Tri Nur Ariani, Eva Dina Chairunisa, Ida Suryani

Perkembangan Sosial Budaya Suku Jawa di Desa Kapasan Tegalrejo BK $X$ Kecamatan Belitang Kabupaten Ogan Komering Ulu Timur Sebagai Sumber Pembelajaran Sejarah di SMA Muhammadiyah 2 Karang Tengah

Ratna Puspita Dewi, Sukardi, Mirza Fansyuri

Pengembangan E-Modul Pembelajaran Sejarah Tokoh-Tokoh Pembangunan

Susi Susanti, Eva Dina Chairunisa

Peran Pendidikan Sejarah Dalam Membentuk Karakter Bangsa

Sukardi, Jeki Sepriady

Sejarah Pengajaran Mantra Melayu di Tengah Perubahan Masyarakat Besemah Muhamad Idris, Eva Dina Chairunisa, Jeki Sepriady

Pengembangan Media Audio Visual Sejarah Kolonialisme Barat di Indonesia Materi Benteng Marlborough Bengkulu Hamza Kurniawan 


\section{Kalpataru}

Jurnal Sejarah dan Pembelajaran Sejarah

Volume 6, Nomor 2, Desember 2020

\section{Chief Editor}

Drs. Sukardi, M.Pd.

\section{Editor}

Dr. Muhamad Idris, M.Pd.

Eva Dina Chairunisa, M.Pd.

Jeki Sepriady, S.Pd.

\begin{tabular}{ll}
\multicolumn{2}{c}{ Reviewer } \\
Dr. Tahrun, M.Pd. & (Universitas PGRI Palembang) \\
Drs. Supriyanto, M.Hum. & (Universitas Sriwijaya Palembang) \\
Dra. Retno Purwati, M.Hum. & (Balai Arkeologi Sumatera Selatan) \\
Dr. Nor Huda Ali, M.Ag., M.A. & (Masyarakat Sejarawan Indonesia Sumsel) \\
Dr. Budi Agung Sudarman, S.S., M.Pd. & (Balai Bahasa Provinsi Sumatera Selatan) \\
Dr. Purmansyah, M.A. & (Universitas Muhammadiyah Palembang)
\end{tabular}

Alamat Redaksi

Program Studi Pendidikan Sejarah

Fakultas Keguruan dan IImu Pendidikan Universitas PGRI Palembang

Telp. 0711-510043

Email: jurnalkalpatarusejarah@gmail.com

Website: https://jurnal.univpgri-palembang.ac.id/index.php/Kalpa 


\section{Kalpataru}

JURNAL SEJARAH DAN

PEMBELAJARAN SEJARAH

Terbit dua kali setahun pada Juli dan Desember

Diterbitkan oleh:

Program Studi Pendidikan Sejarah

Jurusan Pendidikan IPS

Fakultas Keguruan

dan IImu Pendidikan

Universitas PGRI Palembang

\section{Gambar Cover:}

Pohon Kalpataru

Candi Prambanan

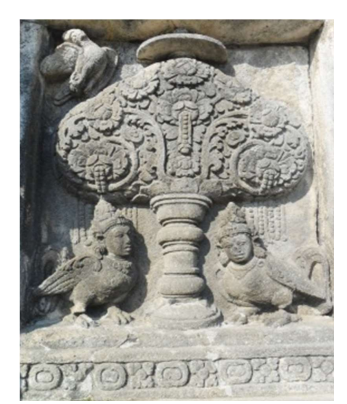

Koleksi: Muhamad Idris 


\section{DAFTAR ISI}

Pengaruh Model Pembelajaran Student Facilitator and Explaining Terhadap Hasil Belajar Siswa Pada Mata Pelajaran Sejarah Kelas X di SMA Negeri 3 Palembang

Sarinah, Nur Ahyani, Ahmad Zamhari 83-89

Pengaruh Model Pembelajaran Berbasis Masalah (PBM) Terhadap Hasil Belajar Siswa Pada Mata Pelajaran IPS Terpadu (Sejarah) Kelas VIII di SMP Negeri 2 Palembang

Neka Dapistri, Nur Ahyani, Ahmad Zamhari..... 90-95

Penerapan Media Pembelajaran Menggunakan Google Earth Dalam Materi Kondisi Masyarakat Indonesia Pada Masa Penjajahan Terhadap Hasil Belajar Siswa Pada Mata Pelajaran IPS Terpadu di SMP Quraniah Palembang

Tri Nur Ariani, Eva Dina Chairunisa, Ida Suryani $96-101$

Perkembangan Sosial Budaya Suku Jawa di Desa Kapasan Tegalrejo BK X Kecamatan Belitang Kabupaten Ogan Komering Ulu Timur Sebagai Sumber Pembelajaran Sejarah di SMA Muhammadiyah 2 Karang Tengah

Ratna Puspita Dewi, Sukardi, Mirza Fansyuri. $102-109$

Pengembangan E-Modul Pembelajaran Sejarah Tokoh-Tokoh Pembangunan Pacsa Kemerdekaan di Sumatera Selatan

Susi Susanti, Eva Dina Chairunisa 110-113

Peran Pendidikan Sejarah Dalam Membentuk Karakter Bangsa

Sukardi, Jeki Sepriady $114-117$

Sejarah Pengajaran Mantra Melayu di Tengah Perubahan Masyarakat Besemah Muhamad Idris, Eva Dina Chairunisa, Jeki Sepriady..... 118-127

Pengembangan Media Audio Visual Sejarah Kolonialisme Barat di Indonesia Materi Benteng Marlborough Bengkulu

Hamza Kurniawan. 128-135 
Kalpataru, Volume 6, Nomor 2, Desember 2020 (110-113)

\title{
PENGEMBANGAN E-MODUL PEMBELAJARAN SEJARAH TOKOH-TOKOH PEMBANGUNAN PACSA KEMERDEKAAN DI SUMATERA SELATAN
}

\author{
Susi Susanti \\ Mahasiswa Program Pendidikan Sejarah FKIP Universitas PGRI Palembang \\ Email: susi.susanti@gmail.com \\ Eva Dina Chairunisa \\ Dosen Program Pendidikan Sejarah FKIP Universitas PGRI Palembang \\ Email: eva.dinach_si@univpgri-palembang.ac.id
}

\begin{abstract}
ABSTRAK
Penelitian ini bertujuan untuk mengetahui langkah dan pengembangan e-modul pembelajaran sejarah tokohtokoh pembangunan pasca kemerdekaan di Sumatera Selatan. E-modul merupakan suatu modul berbasis TIK. Rumasan masalah dalam penilitian ini bagaimana pengembangan e-modul pembelajaran sejarah tokoh-tokoh pembangunan pasca kemerdekaan di Sumatera Selatan. Manfaat penelitian adalah bagi siswa dapat mengembangkan kemampuan berfikir dan bagi guru, tersedianya sumber pembelajaran sejarah pada materi sejarah Indonesia. Penelitian yang digunakan metode penelitian dan pengembangan (R\&D) adalah metode penelitian yang digunakan untuk menghasikan produk tertentu dan menguji keefektifan metode tersebut. Dengan menggunakan teknik pengumpulan data melalui observasi langsung ke lokasi penelitian. Dari hasil penelitian dapat disimpulkan bahwa hasil penelitian yang diperoleh menujukkan e-modul pembelajaran sejarah yang dikembangkan layak digunakan sebagai media pembelajaran guru dan siswa dalam proses kegiatan belajar mengajar berdasarkan perolehan nilai rata-rata keseluruhan skor aspek dari ketiga validator yaitu pada aspek penyajian dan pemanfaatan yaitu $92,7 \%$, aspek isi materi dan strategi pembelajaran yaitu $90 \%$, dan aspek keseluruhan skor dari aspek respon siswa terhadap e-modul yaitu 89,2\% dengan kategori sangat layak.
\end{abstract}

Kata Kunci: Pengembangan E-modul Sejarah, Tokoh-Tokoh pasca, Sigil.

\section{A. PENDAHULUAN}

Bahan ajar memiliki peran yang penting dalam setiap pembelajaran termasuk dalam pembelajaran Sejarah. Oleh karena itu, pembelajaran terpadu pada dasarnya merupakan perpaduan dari berbagai disiplin ilmu yang tercakup dalam ilmu-ilmu sosial, maka implikasi terhadap pembelajaran diperlukan bahan ajar yang lebih lengkap, komprehensif dan mampu memandu siswa dalam membangun dan kompetesinya dibandingkan dengan pembelajaran monolitik.

Sejarah lokal sebagai muatan lokal penting disamapaikan dalam pembelajaran bukan hanya siswa, guru, materi, dan sarana, tetapi juga lingkungan sekitar. Lingkungan yang banyak peninggalan sejarah dan tradisinya menjadi bagian proses belajar mengajar (Suprijono, 2011:59).

Menurut Sunarto

(2006:23)

pembelajaran sejarah lokal pemahaman bagi kehudupan masyarakat terutama masyarakat modern. Pada dasarnya mempelajari sejarah lokal sangat bermanfaat yakni sebagai sumber kreativitas dan pandangan optimis masyarakat lokal. Dengan bahwa masyarakat tradisional mungkin hanya berbuat sesuai dengan tentang seketika yang mereka temukan, tetapi masyarakat medorn tidak bisa terpaku pada kekinian. Sejarah lokal memberikan pelajaran untuk menghadapi tantangan yang akan.

Sejarah lokal sebagai pengikat kesadaran multikulturalisme dalam suatu bangsa adalah kesadaran sejarah. Pendidikan sejarah berperan penting dalam internalisasi dan pembangunan kesadaran sejarah. Disimpulkan bahwa sejarah lokal pada dasarnya mempelajari sejarah lokal sangat bermanfaat yakni sebagai sumber kreativitas dan pandangan optimis masyarakat lokal yang disampaikan dalam pembelajaran bukan hanya siswa guru, matari, dan sarana, tapi juga lingkungan sekitar dalam pengikat kedasar multikulturalisme sesuatu bangsa. 


\section{Kalpataru, Volume 6, Nomor 2, Desember 2020 (110-113)}

Bahan ajar yang digunakan itu disusun lebih sistematis berupa modul. Modul adalah bahan ajar belajar yang dirancang secara sistematis berdasarkan kurikulum tertentu dan dikemas dalam bentuk satuan pembelajaran terkecil dan memungkinkan dipelajari secara mandiri dalam satuan waktu tertentu (Puwanto, 2007:9). Modul dapat membantu siswa dalam menguasai materi pelajaran secara mandiri akan tertapi modul juga dapat membuat siswa merasa bosan karena kurang menariknya dalam penyampaian materi maka peneliti memberikan solusi atau jalan keluar dari permasalah tersebut dengan mengubah modul menjadi lebih menarik lagi yaitu modul menjadi e-modul sehingga dapat meningkatkan semangat belajar siswa. E-Modul merupakan adaptasi modul cetak yang dikembang ke modul elekronik, di dalam modul elekronik (emodul) terdapat uraian materi, animasi/ilustrasi/simulasi yang menjelaskan sebuah pemahaman konsep pembelajaran sejarah ini.

\section{B. METODE PENELITIAN}

Menurut Suharsimi mengatakan bahwa metode penelitian adalah cara yang digunakan oleh peneliti dalam mengumpulkan data penelitiannya (Arikunto, 2010:203). Penelitian ini mengembangkan e-modul pada kompetensi tokoh-tokoh sipil. Penelitian pengembangan adalah metode pelitian yang digunakan untuk menghasilkan produk tertentu dan menguji keefektifan produk tersebut.

\section{Teknik Pengumpulan Data Angket}

Kuisioner atau angket merupakan metode pengumpulan data untuk memahami individu dengan cara memberikan suatu daftar pertanyaan tentang berbagai aspek kepribadian individu. Dengan kuisioner, konselor dapat memperoleh berbagai macam data tentang individu dalam waktu yang relatif singkat. Karena itu dibandingkan ddengan metode pemahaman individu yang lain, kuisioner mempunyai keunggulan dalam hal dapat dilakukan secara masal, dalam waktu pendek, dan mampu mengungkap berbagai aspek kerpribadian individu (Widodo, 2018:7).

\section{Dokumentasi}

Dokumentasi ialah pengambilan data yang diperoleh melalui dokumen-dokumen. Keuntungan menggunakan dokumentasi ialah biayanya lebih murah, waktu dan tenaga lebih efisien, sedangkan kelemahannya ialah data yang diambil dari dokumen cenderung sudah lama, dan kalau ada yang salah cetak, maka peneliti ikut salah pula mengambil datanya. Data-data yang dikumpulkan dengan teknik dokumentasi cenderung merupakan data sekunder, sedangkan data-data yang dikumpulkan dengan teknik observasi, wawancara, dan angket cenderung merupakan data primer atau data yang langsung didapat dari pihak pertama (Sugiyono, 2008:11).

\section{Observasi}

Observasi adalah pengamatan data dengan menggunakan mata tanpa standar, tetapi mempunyai kriteria berikut:

1. Pengamatan untuk penelitian yang direncanakan secara sistematis.

2. Pengamatan harus berkaitan dengan tujuan penelitian.

3. Penelitian dicatat secara sistematis dan dihubungkan dengan proposisi umum dan bukan dipaparkan sebagai suatu set yang menarik perhatian saja.

4. Pengamatan dapat dicek dan dikontrol atas validasi dan realibilitasnya.

\section{Wawancara}

Wawancara adalah merupakan pertemuan dua orang untuk bertukar informasi dan ide melalui tanya jawab, sehingga dapat dikontruksikan makna dalam suatu topik tertentu (Sugiyono, 2015:9).

Wawancara digunakan sebagai teknik pengumpulan data apabila peneliti ingin melakukan studi pendahuluan untuk menentukan permasalahan yang harus diteliti, dan juga apabila peneliti ingin mengetahui halhal dari responden yang lebih mendalam dan jumlah respondennya sedikit, teknik pengumpulan data ini mendasarkan diri pada laporan tentang diri sendiri atau self-report, atau setidak-tidaknya pada pengetahuan dan keyakinan pribadi (Sugiyono, 2015:10). 


\section{Teknik Analisis Data}

Teknik analisis data yang dilakukan yaitu menggunakan teknik analisis deskriftif yang artinya memaparkan hasil pengembangan produk yang berupa media pembelajaran emodul. Data yang terkumpul diproses dengan cara dijumlahkan, dibandingkan dengan jumlah yang diharapkan dan diperoleh persentase dengan rumus sebagai berikut.

Persentase Kelayakan

$(\%)=\frac{\text { Skorhasilobserv }}{\text { Skoryangdihar }} \times 100 \%$

\section{HASIL DAN PEMBAHASAN}

Penilaian Guru Mata Pelajaran Sejarah Untuk Media

\begin{tabular}{|c|c|c|c|c|}
\hline No & Aspek Penilaian & $\begin{array}{c}\text { Total } \\
\text { Penilaian }\end{array}$ & $\begin{array}{c}\text { Penilaian } \\
\text { yang } \\
\text { diharapkan }\end{array}$ & $\begin{array}{c}\text { Persentase } \\
\text { Kualitas } \\
\text { Media }\end{array}$ \\
\hline 1. & Isi materi & 37 & 40 & $92,5 \%$ \\
\hline 2. & $\begin{array}{c}\text { Strategi } \\
\text { pembelajaran }\end{array}$ & 9 & 10 & $90 \%$ \\
\hline \multicolumn{2}{|c|}{ Jumlah } & $\mathbf{4 6}$ & $\mathbf{5 0}$ & $\mathbf{9 2 \%}$ \\
\hline
\end{tabular}

Berdasarkan pengamatan dari tabel diatas menunjukkan bawah penilaian pada media pembelajaran e-modul dari ahli media pembelajaran yang dilihat dari aspek isi materi penilaian adalah 37 poin penilaian yang diharapkan mendapatkan 40 poin dari total penilaian dan persentase penelitian kuliatas media pembelajaran sebesar $92,5 \%$. Dengan skala persentase dari tabel di atas hasil yang di peroleh adalah "Sangat Baik" untuk isi materi. Dilihat dari aspek Strategi Pembelajaran adalah 9 poin, penilaian yang diharapkan mendapatkan 10 poin dari total penilaian dan persentase kualitas media pembelajaran sebesar $90 \%$. Dengan skala persentase dari hasil tabel di atas diperoleh adalah "Sangat Baik" untuk di strategi pembelajaran. Rata-rata jumlah penilaian dari ahli media pembelajaran e-modul sebesar 92\%. Dengan skala persentase dari hasil tabel diatas dapat diperoleh hasil yang menujukkan bahwa termasuk dalam kategori "Sangat Baik" untuk digunakan.

\section{Data Hasil Uji Penggunaan Media Oleh Siswa}

Hasil yang diuji dengan penggunaan media e-modul oleh siswa yang diambil sampel sebanyak 7 orang dari 30 siswa kelas XII IPA 1 SMA Negeri 1 Palembang. Adapun persentase data hasil penilaian uji kelompok yang diberikan kepada siswa dapat disajikan pada tabel bawah ini.

\begin{tabular}{|c|c|c|c|c|c|c|c|c|c|c|c|}
\hline \multirow{2}{*}{$\begin{array}{c}\text { No } \\
\text { Resp } \\
\text { onden }\end{array}$} & \multicolumn{7}{|c|}{ Nomor Butir Angket } & \multicolumn{1}{c|}{$\begin{array}{c}\text { Skor } \\
\text { Total }\end{array}$} \\
\hline & 1 & 2 & 3 & 4 & $\mathbf{5}$ & $\mathbf{6}$ & $\mathbf{7}$ & $\mathbf{8}$ & $\mathbf{9}$ & & \\
\hline 1 & 5 & 4 & 4 & 5 & 5 & 4 & 5 & 5 & 5 & 4 & 46 \\
\hline 2 & 4 & 4 & 4 & 5 & 4 & 4 & 5 & 4 & 4 & 4 & 42 \\
\hline 3 & 5 & 4 & 4 & 4 & 5 & 5 & 5 & 5 & 4 & 4 & 45 \\
\hline 4 & 5 & 4 & 5 & 4 & 5 & 4 & 5 & 5 & 4 & 4 & 45 \\
\hline 5 & 5 & 5 & 5 & 5 & 4 & 4 & 4 & 4 & 5 & 5 & 46 \\
\hline 6 & 4 & 4 & 5 & 4 & 5 & 5 & 5 & 4 & 5 & 4 & 45 \\
\hline 7 & 4 & 5 & 5 & 5 & 5 & 4 & 4 & 5 & 4 & 5 & 46 \\
\hline 8 & 5 & 5 & 5 & 4 & 4 & 5 & 4 & 5 & 5 & 4 & 46 \\
\hline 9 & 5 & 4 & 4 & 5 & 5 & 4 & 4 & 5 & 5 & 5 & 46 \\
\hline 10 & 5 & 5 & 4 & 4 & 4 & 5 & 5 & 5 & 4 & 4 & 45 \\
\hline
\end{tabular}

Tabel Hasil penilaian Siswa

\begin{tabular}{|c|c|c|c|}
\hline $\begin{array}{c}\text { Nomor } \\
\text { Rosponden }\end{array}$ & Total Penilaian & $\begin{array}{c}\text { Penilaian di } \\
\text { harapkan }\end{array}$ & $\begin{array}{c}\text { Persentase } \\
\text { Kualitas media }\end{array}$ \\
\hline 1 & 46 & 50 & $92 \%$ \\
\hline 2 & 42 & 50 & $84 \%$ \\
\hline 3 & 45 & 50 & $90 \%$ \\
\hline 4 & 45 & 50 & $90 \%$ \\
\hline 5 & 46 & 50 & $92 \%$ \\
\hline 6 & 45 & 50 & $90 \%$ \\
\hline 7 & 46 & 50 & $92 \%$ \\
\hline 8 & 46 & 50 & $92 \%$ \\
\hline 9 & 46 & 50 & $92 \%$ \\
\hline 10 & 45 & 50 & $90 \%$ \\
\hline Jumlah & 446 & 500 & $89,2 \%$ \\
\hline
\end{tabular}

D.

\section{IMPULAN}

Berdasarkan hasil dari penelitian pengembangan e-modul Media pengembangan e-modul berbasis sigil untuk menghasilkan emodul belajar sejarah sebagai media pengembangan e-modul seharusnya dapat digunakan pada setiap materi, karena dapat menberikan ketertarikan pada siswa untuk belajar seharusnya guru memanfaat aplikasi sigil sebaik mungkin dan berdasarkan hasil penelitian dan analisis data, hal ini dapat dilihat bahwa kelas XII SMA Negeri 1 Palembang memiliki rata-rata skor $89,2 \%$. 


\section{DAFTAR PUSTAKA}

Arikunto, Suharsimi. 2010. Prosedur Penelitian. Jakarta: Rineka Cipta.

Puwanto, Aristo Rahadi dan Suharto Lasmono. 2009. Pengembangan Modul. Jakarta: Pustekkom.

Sugiyono. 2008. Memahami Penelitian Kualitatif. Bandung: Alfabeta.

Sugiyono. 2015. Metode PenelaianPendidikan. Bandung: Alfabeta.

Sunarto, H dan Agung Hartono B. 2006. Perkembang Peserta Didik. Jakarta: Rineka Cipta.

Suprijono, Agus. 2011. Cooperative Leaning Teori dan Aplikasi Falkem. Yogyakarta: Pustaka.

Widodo, G. 2018. Pengembangan E-modul perang Kemerdekaan di Jember Berbasis Project Based Learning Menggunakan Model ADDIE Untuk SMA Kelas XI IPS. Jember: Program Studi Pendidikan Sejarah, Universitas Jember. 


\section{KETENTUAN PENULISAN ARTIKEL JURNAL KALPATARU}

1. Naskah berbahasa Indonesia yang disempurnakan bertemakan kesejarah yang meliputi hasil penelitian sejarah, pengajaran sejarah dan penelitian kebudayaan.

2. Naskah harus asli dan belum pernah dimuat dalam media lain. Naskah dapat berupa hasil penelitian/artikel kajian konseptual yang ditulis oleh perorangan dan atau kelompok.

3. Naskah ditulis dengan cara-cara yang sesuai dengan ketentuan penulisan artikel ilmiah menggunakan bahasa Indonesia yang baku, berupa ketikan, beserta soft file dalam CD-RW atau dengan mengirimkan email pada redaksi jurnal Kalpataru dengan alamat jurnalkalpatarusejarah@gmail.com, spasi tunggal, jenis huruf arial narrow ukuran 12, dengan panjang naskah antara 8-15 halaman pada kertas A4.

4. Artikel hasil penelitian memuat:

JUDUL

Nama Penulis

Abstrak

A. PENDAHULUAN

B. METODE PENELITIAN

C. HASIL DAN PEMBAHASAN

D. SIMPULAN

DAFTAR PUSTAKA
: XXX (HURUF KAPITAL)

: (disertai jabatan, institusi, dan email)

: (Bahasa Indonesia yang memuat 100-200 kata diikuti kata kunci, dengan jenis huruf arrial narrow dan ukuran huruf 11 serta dicetak miring).

: (memuat latar belakang masalah, tinjauan pustaka secara ringkas, masalah penelitian, dan tujuan penelitian).

5. Artikel Kajian Konseptual memuat:

JUDUL

Nama Penulis

Abstrak

PENDAHULUAN

Sub Judul

Simpulan

DAFTAR PUSTAKA
: (berisi simpulan).

: (berisi pustaka yang dirujuk dalam uraian naskah).

6. Referensi sumber dalam teks artikel ditulis dengan menggunakan side note, contoh (Jalaludin, 1991:79); sementara penulisan daftar pustaka disusun dengan ketentuan. Nama pengarang. Tahun terbit. Judul (dicetak miring). Kota terbit: Nama Penerbit. Contoh: Koentjaraningrat. 2010. Manusia dan Kebudayaan di Indonesia. Jakarta: Djambatan. Daftar pustaka hanya memuat pustaka/sumber yang dirujuk dalam uraian dan disusun menurut abjad tanpa nomor urut.

7. Naskah yang dimuat akan disunting kembali oleh redaksi tanpa mengubah isinya.

8. Naskah yang ditolak (tidak bisa dimuat) akan dikirim kembali ke penulis dengan pemberitahuan tertulis dari redaksi atau melalui email.

9. Penulis yang naskahnya dimuat akan mendapat 1 (satu) majalah nomor yang bersangkutan.

10.Kontak person: Muhamad Idris (081271498618); Eva Dina Chairunisa (082281267851); Jeki Sepriady (085269261780). 